\title{
BIOEDUSCIENCE
}

ISSN: 2614-1558

http://journal.uhamka.ac.id/index.php/bioeduscience

\section{Application of a Four-Tier Diagnosis Test for Evaluating Student's Misconception about Blood Classification}

\author{
Syarafina ${ }^{1,2}$, Zainul Mustofa $^{3 *}$ \\ 1 Pendidikan Biologi, IKIP Budi Utomo, Jalan Simpang Arjuno No. 14 B, Kota Malang, Jawa Timur, Indonesia 65119 \\ 2 SMP Jawahirul Hikmah, Besuki, Tulungagung, Jawa Timur, Indonesia 66275 \\ ${ }_{3}^{3}$ SMK Al Munawwariyyah, Jalan Sudimoro No. 9, Bululawang, Malang, Jawa Timur, Indonesia 65171 \\ *Corespondent email: zainulmustofa1993@yahoo.com
}

\section{ARTICLE INFO:}

Article history:

Received: 19 Apr 2020

Accepted: 11 Des 2020

Published: 31 Des 2020

\section{Keywords:}

Blood Component

Blood Classification

Four Tier

Misconception

\section{A B S T R A C T}

Background: A misconception is a form of error in scientific knowledge that is believed to be accurate. As a result, someone who has a misconception of something will reject scientific truth and will hinder the assimilation of new knowledge. The purpose of this study was to identify misconceptions that occur in students regarding the topic of blood classification. Methods: The survey method research was conducted on 97 students scattered in Malang and Tulungagung, Indonesia. The data analysis technique uses coding for categorization into four categories: conceptual understanding, partial understanding, misconception, and not understanding the concept. Results: The results showed that misconceptions occurred in all sub-topics of blood classification. Misconceptions were found in the concept of blood plasma (2.1\%), white blood cells (6.2\%), thrombocytes (17.5\%), and blood classification system (8.2\%). Misconceptions occur due to several misunderstandings of students such as red blood cells that play a role in transporting nutrients, haemoglobin only binds oxygen, and difficulty distinguishing between antigens and antibodies in determining blood groups, blood donation, and the impact arising from donations. Conclusion: The existence of misconceptions causes students' mastery of blood classification material to be hampered.

\section{Penerapan Tes Diagnosis Four-Tier untuk Mengevaluasi Miskonsepsi Siswa tentang} Klasifikasi Darah

\section{A B S T R A K}

Background: Miskonsepsi merupakan salah satu bentuk kesalahan pengetahuan ilmiah yang diyakini kebenarannya. Akibatnya seseorang yang miskonsepsi terhadap suatu hal akan cenderung menolak kebenaran ilmiah dan tentunya akan menghambat proses asimilasi pengetahuan baru. Tujuan penelitian ini adalah untuk mengidentifikasi miskonsepsi yang terjadi pada siswa terkait topik klasifikasi darah. Metode: Penelitian dengan metode survei dilakukan pada 97 siswa yang tersebar di Malang dan Tulungagung, Indonesia. Teknik analisis data menggunakan pengkodean untuk pengkategorian pada empat jenis kategori yaitu paham konsep, paham sebagian, miskonsepsi, dan tidak paham konsep. Hasil: Hasil penelitian menunjukkan bahwa miskonsepsi terjadi pada semua sub topik klasifikasi darah. Ditemukan miskonsepsi pada konsep plasma darah $(2,1 \%)$, sel darah putih $(6,2 \%)$, keping darah $(17,5 \%)$ dan sistem penggolongan darah $(8,2 \%)$. Miskonsepsi terjadi karena beberapa kesalahan pemahaman siswa seperti sel darah merah berperan dalam mengangkut nutrisi, hemoglobin hanya mengikat oksigen, dan kesulitan membedakan antara antigen dan antibodi pada penentuan golongan darah, pendonoran darah, dan dampak yang timbul dari pendonoran. Kesimpulan: Adanya miskonsepsi menyebabkan penguasaan siswa terhadap materi klasifikasi darah menjadi terhambat. 


\section{Introduction}

The main objective of learning science is to understand the basic concepts of science in depth. A good understanding of concepts will make it easier for students to develop their abilities in various aspects in the era of globalization (Mustofa, 2019). This close relationship is because before they reach higher-order thinking skills such as critical and creative thinking, they must pass through the stage of understanding the concepts of science being studied. This is why research related to conceptual understanding remains a relevant and most important topic in science education research. Widiyatmoko \& Shimizu, (2018) Understanding the concept of science is essential in today's life, considering that the community's role in contributing to conveying opinions and policy proposals related to the surrounding environment is very vital.

Current science education research is divided into several sections/research focuses. First, it focuses on the extent to which students understand concepts, including identifying misconceptions, concept difficulties, and concept application (Mustofa, 2018; Mustofa et al., 2016). Second, it focuses on preparing lessons that can improve students' abilities in various aspects including problemsolving (Mustofa \& Asmichatin, 2019), critical and creative thinking (Fatmawati et al., 2019), and abilities. Collaboration (Fuad et al., 2019). Third, some focus on developing learning media, both online and offline (Mustofa, 2019). These three main research focuses are continuously explored to find better solutions in the field of science education.

One rarely studied problem is research related to misconceptions and conceptual difficulties on specific topics and focuses. Exploration related to misconceptions requires a diagnostic tool. (Soeharto, B., C., E., S., F.I. \& T., 2019) reported that diagnostic tests that have been used include interview tests, simple multiple-choice, multilevel multiple-choice, and open-ended questions. Of the many forms of tests, multilevel multiple choices tests can be more comfortable in mapping student answers. The four-tier multilevel multiple-choice test is free of error and misunderstanding diagnostic test, which is very practical and useful for diagnosing misconceptions. The effectiveness of the four-tier has succeeded in identifying misconceptions in various concepts such as fluid (Dewi et al., 2019), vibration and waves (Negoro \& Karina, 2019), kinematics (Pujayanto, 2018), and heart and blood vessels (Syarafina

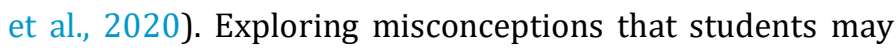
experience is important to develop how learning will be given to students. If this diagnostic nuance is applied thoroughly to students before and after learning, it can be believed that students will be mapped how their understanding is related to what is learned.
One important topic and often causes misconceptions are the components of blood and the blood grouping system, which is part of humans' circulatory system. The misconception of the circulatory system in humans occurs from elementary to university, with a decreasing trend with higher levels of education (Özgür, 2013). At the junior high school level, this material is a new material for them. Without a good understanding of blood components, students will find it challenging to explain the various mechanisms in the body. For example, students must understand thrombocytes when explaining the blood clotting mechanism because not all blood can perform this function. Likewise, the basic concept of the most straightforward $\mathrm{ABO}$ blood grouping system.

A good mastery of concepts has not followed the importance of understanding blood components and blood grouping. This is evident from several reports that state the existence of misconceptions in blood material. The report results show that the average value of misconceptions at the junior high school level on the topic of the circulatory system is still low (28.3\%) (Alfionitari et al., 2019). Even at a higher level, namely SMA, the misconception on the circulatory system material is relatively high, namely $56.21 \%$ (Khairaty et al., 2018). Therefore, this study focuses on identifying student misconceptions on blood classification in humans using a four-tier multiple-choice test instrument.

\section{Methods}

This research is a quantitative descriptive study with a survey method to obtain the data. The research was conducted in two schools in Malang district, Indonesia. The research was conducted in the odd semester 2019/2020 academic year. The research subjects consisted of 97 students. In general, these three schools apply a scientific approach to learning. The learning applied to each of these schools uses discovery learning models by utilizing the biology teaching aids owned by each school.

The data were obtained from students' answers while working on the four-tier multiple-choice test. The number of questions consists of 5 items, namely four items about blood components and 1 item about the blood grouping system (See Appendix). Difficulty level, difference power, correlation of each item can be seen in Table 1. This instrument has a Cronbach's Alpha coefficient value of 0.597 (good category) after being tested on 80 respondents who had studied material about blood components and the ABO blood group system. This value means that this instrument has a high enough consistency to diagnose students' understanding of the concept of components and the blood classification system.

The question instruments that the students had worked on were then collected and coded. The coding of the students' answers follows the rules in Table 2. This coding 
is divided into four categories: understanding the concept, partially understanding, misconception, and not understanding it. The way to use Table 2 , the coding system is to adjust student responses to each item and at each level.

Table 1. Characteristics of Question Items

\begin{tabular}{cccccc}
\hline Item & Concept Problem & Part of Questions & Difficulty Level & Differences Level & Correlation \\
\hline $\mathbf{1}$ & Blood Plasma & Question & 0,60 & 0,78 & 0,61 \\
& & Reason & 0,68 & 0,30 & 0,35 \\
$\mathbf{2}$ & \multirow{2}{*}{ Red Blood Cells } & Question & 0,79 & 0,37 & 0,52 \\
& & Reason & 0,47 & 0,59 & 0,39 \\
$\mathbf{3}$ & White Blood Cell & Question & 0,73 & 0,41 & 0,54 \\
& & Reason & 0,51 & 0,85 & 0,40 \\
$\mathbf{4}$ & \multirow{2}{*}{ Blood Plate } & Question & 0,58 & 0,70 & 0,15 \\
& & Reason & 0,53 & 0,53 & 0,24 \\
& \multirow{5}{*}{ Blood Type } & Question & 0,69 & 0,63 & 0,44 \\
\hline
\end{tabular}

Table 2. Encoding on Four Tier Test Answers

\begin{tabular}{|c|c|c|c|c|c|}
\hline \multirow{2}{*}{ No } & \multirow{2}{*}{ Category } & \multicolumn{4}{|c|}{ Combination of Answers } \\
\hline & & Answer & Confidence Level & Reasons & Confidence Level \\
\hline 1 & Understand the Concept & Right & Sure & Right & Sure \\
\hline 2 & & Right & Sure & Right & Not sure \\
\hline 3 & & Right & Not sure & Right & Not sure \\
\hline 4 & & Right & Sure & False & Sure \\
\hline 5 & & Right & Sure & False & Not sure \\
\hline 6 & Partial Understanding & Right & Not sure & False & Sure \\
\hline 7 & & Right & Not sure & False & Not sure \\
\hline 8 & & False & Sure & Right & Sure \\
\hline 9 & & False & Sure & Right & Not sure \\
\hline 10 & & False & Not sure & Right & Sure \\
\hline 11 & Misconception & False & Sure & False & Sure \\
\hline 12 & & False & Sure & False & Not sure \\
\hline 13 & Don't Understand the Concept & False & Not sure & False & sure \\
\hline 14 & & False & Not sure & False & Not sure \\
\hline 15 & Cannot be coded & \multicolumn{4}{|c|}{ Not answered one, two, three or all } \\
\hline
\end{tabular}

Data Source: Dewi et al. (2019)

For example: If a student gives a correct choice response on a first-level question (answer), gives a confident response at the second level (confidence answers), gives a correct choice response at level three (reason), and gives a choice response unsure at level four (confidence reason), then the overall student response is included in code 2 with the partial understanding category. Through this coding system, there are 485 coding results obtained from 5 questions x 97 respondents. After the data has been coded and mapped, each item will be discussed further on how students understand based on the distribution data of students' answers on each item.

\section{Results}

\section{Students' Understanding of Blood Components}

\section{Blood plasma}

Items to access students' understanding of blood plasma components are presented in the Appendix. To successfully answer this question, students must understand some of the basic properties of blood plasma, namely (1) it is liquid; (2) functions to transport nutrients; and (3) the largest component of blood. The results of the distribution of students' answers are presented in Table 3. Based on these data, it appears that only $41.2 \%$ of students understand deeply after learning, the rest only partially understand, misconceptions and do not understand concepts at all.

Table 3. Distribution of Student Answers to Blood Plasma Problems

\begin{tabular}{lcc}
\hline \multicolumn{1}{c}{ Category } & Number & Percentage (\%) \\
\hline Understand & 40 & 41,2 \\
Partial Understanding & 40 & 41,2 \\
Misconception & 2 & 2,1 \\
Don't Understand & 15 & 15,5 \\
\hline
\end{tabular}

The results of an in-depth analysis of the students' answers indicated that item number 1 (question) of the 
distribution of choice A was answered by 58 students, choice B by 20 students, choice $C$ by three students, and choice $\mathrm{D}$ by 16 students. The most incorrect answer chosen by the student is choice $B$. Based on the researcher's hypothetical problem, it is estimated that the student understands that the blood in his life is often liquid and red, so when given the question, he answers red blood cells. Meanwhile, an in-depth search of the students' reasons when answering it was found that 66 students chose A, 13 students chose $B$, ten students chose $C$, and eight students chose D. Those who did not answer correctly had a mixed understanding of some of the blood functions they had encountered, such as clotting, transporting nutrients and binding oxygen as they had previously learned in elementary school.

\section{Red Blood Cells (Erythrocytes)}

Questions to reveal how deep the students' understanding of erythrocytes' components in the blood is presented in the Appendix. To get the right answer to this problem, students must understand the essential characteristics of red blood cells, namely (1) in the form of a biconcave (concave); (2) functions to bind oxygen and carbon dioxide in the blood; and (3) contains haemoglobin which causes red colour. The analysis results of the distribution of students' answers to the questions in Figure 2 are presented in Table 4 . Based on the data, it appears that there are no students who experience misconceptions in this discussion. However, most students understand this concept partially, namely as much as $57.7 \%$.

Table 4. Distribution of Students' Answers to Red Blood Cells (Erythrocytes)

\begin{tabular}{lcc}
\hline \multicolumn{1}{c}{ Category } & Number & Percentage (\%) \\
\hline Understand & 31 & 32,0 \\
Partial Understanding & 56 & 57,7 \\
Misconception & 0 & 0,0 \\
Don't Understand & 20 & 10,3 \\
\hline
\end{tabular}

The results of the in-depth analysis of the distribution of the students' answers showed that (1) 10 students answered the question item A, 77 students answered choice B, 4 students chose C, 6 students answered it; (2) item reasons, choice A by 30 students, choice B by 19 students, choice C by 46 students, and choice D by 2 students. Based on these details, it is clear that choice of reason $\mathrm{A}$ is the wrong choice chosen by students $(30.9 \%)$, and choice of reason $B$ is the second wrong choice (19.5\%). This shows that students assume that hemoglobin only binds to $\mathrm{O}_{2}$ or $\mathrm{CO}_{2}$.

\section{White Blood Cells (Leukocytes)}

The way to find out the understanding of students concepts related to white blood cells (leukocytes) is by giving questions as presented in the Appendix. To answer this item correctly must master some basic concepts related to white blood cells, namely (1) functions to fight germs that enter the body; (2) the shape is not fixed, has a nucleus and can move amoeboid dally; (3) white blood cells are divided into two types, namely granular and nongranular, each of which has a different function when fighting germs. The results of the distribution of students' answers to item number 3 are presented in Table 5. Based on the distribution of student responses in Table 5, it appears that most students understand only part of the concept, which is $59.8 \%$. Only about $30 \%$ of students fully understand the concept of white blood cells.

The results of the examination of the distribution of students' answers obtained the following results: (1) the answer to question 6 students chose a, four students chose answer B by four students, 71 students chose answer C, and 16 students chose answer D; (2) choice of reason A by 17 students, choice of reason B by 49 students, choice of reason $C$ by 16 students, and choice of reason $D$ by 15 students. Based on this in-depth data, it appears that the most important choice of errors is the choice of reason A. Based on the researcher's hypothesis when developing the instrument, it can be assumed that students think that granules are a kind of tool to fight germs.

Table 5. Distribution of Students' Answers to White Blood Cells (Leukocytes) Problems

\begin{tabular}{lcc}
\hline \multicolumn{1}{c}{ Category } & Number & Percentage (\%) \\
\hline Understand & 28 & 28,8 \\
Partial Understanding & 58 & 59,8 \\
Misconception & 6 & 6,2 \\
Don't Understand & 5 & 5,2 \\
\hline
\end{tabular}

\section{Blood Plate (Thrombocytes)}

Questions to access students' understanding of thrombocytes are presented in the Appendix. To successfully answer this question, students must understand some of the essential characteristics of thrombocytes, namely (1) it plays an essential role in blood clotting; (2) in the thrombocytes there is the enzyme thrombokinase or thromboplastin which plays an important role in the formation of fibrin threads so that the wound is closed. Student responses to the questions in Figure 4 are presented in Table 6 . Based on these data, it appears that $38.1 \%$ of students understand the concept, $35.1 \%$ of students understand the concept only partially, $17.5 \%$ of students experience misconceptions, and $9.3 \%$ students do not understand the concept.

Table 6. Distribution of Students' Answers to Thrombocytes

\begin{tabular}{lcc}
\hline \multicolumn{1}{c}{ Category } & Number & Percentage (\%) \\
\hline Understand & 37 & 38,1 \\
Partial Understanding & 34 & 35,1 \\
Misconception & 17 & 17,5 \\
Don't Understand & 9 & 9,3 \\
\hline
\end{tabular}


The results of an in-depth analysis of the distribution of student answer choices were also carried out to support these data. Answer choice A was chosen by eight students, answer choice B by 11 students, answer choice C by 22 students, and answer choice D by 56 students. Choice of reason 51 students chose A, choice of reason B by 13 students, choice of reason $C$ by 11 students, and choice of reason $\mathrm{D}$ by 22 students.

\section{Students' Understanding of the ABO Blood Classification System}

The question instrument to test students understanding of the $\mathrm{ABO}$ blood grouping system concept is presented in the Appendix. To successfully answer this question, at least some basic concepts of the $\mathrm{ABO}$ blood grouping system must be mastered: agglutinogens/antigens and (2) agglutinins/antibodies; (2) blood group $\mathrm{O}$ has anti-A and Anti-B antibodies and has no antigen; (3) To prevent clots from occurring, a patient with blood type 0 must receive a donor from a person with type 0 blood as well. The distribution of student answers related to the questions is presented in Table 7.

Table 7. Distribution of Student Answers to the ABO Blood Classification System Questions

\begin{tabular}{lcc}
\hline \multicolumn{1}{c}{ Category } & Number & Percentage (\%) \\
\hline Understand & 24 & 24,7 \\
Partial Understanding & 61 & 62,9 \\
Misconception & 8 & 8,2 \\
Don't Understand & 4 & 4,1 \\
\hline
\end{tabular}

The analysis results of the distribution of students responses to multiple-choice questions were used for a more in-depth analysis. Choice of answer A was chosen by 4 students, choice of answer B by three students, choice of answer C by 23 students, and choice of answer D by 67 students. Choice of reason 33 students chose reason $\mathrm{B}$ by 46 students, choice of reason $C$ by 12 students, and choice of reason D by 6 students.

\section{Discussions}

The results of the analysis of students' understanding regarding blood plasma showed that most students had a partial understanding of this concept. There are about $20.6 \%$ of students think that red blood cells play a role in transporting nutrients in the body. This result is supported by the research of (Khairaty et al., 2018) who found misconceptions related to red blood cells as a component that plays a role in the transport of nutrients. Analysis related to students' understanding of red blood cells showed that $57.7 \%$ of students only understood part of the concept. They assume that red blood cells play a role in binding oxygen or carbon dioxide only. Most of those who answered wrongly assumed that all it needed was oxygen in life, even though carbon dioxide also needed to be bound by haemoglobin and excreted. This is by the research of (Kurt et al., 2013) who found that some students in their class thought that haemoglobin only binds to oxygen.

In the questions about white blood cells, about $60 \%$ of students only understood part of it. Some students incorrectly argued that the part of white blood cells that functions to fight germs is granular. Student responses to the platelet questions showed that there were $17.5 \%$ of students had misconceptions. Those who mistakenly think that thrombocytes have antibodies that make the wound close quickly.

The results of the analysis of students' understanding regarding the concept of blood grouping showed that $62.9 \%$ of students only understood part of it. The results showed that they understood that blood type $\mathrm{O}$ is a universal donor and blood group 0 can only accept blood group 0 , but cannot explain it correctly. They have difficulty distinguishing between antigens and antibodies. This is following the research of (Alfionitari et al., 2019) who found that around $70.2 \%$ of students had difficulty determining blood groups and donations due to difficulties in distinguishing between antigens and antibodies.

There are several ways to remediate students who experience misconceptions, do not understand concepts, and understand some concepts. The application of modelling learning can be chosen to overcome this problem because modelling students play an active role in modelling phenomena, validating and testing them (Mustofa et al., 2019; Mustofa \& Asmichatin, 2019). Another way can be done by providing some suitable learning media, for example with the torso, props, animation, and simulation simultaneously to strengthen each other (Aisyah \& Widiyanto, B., Fatkhurrohman, 2019).

\section{Conclusions}

Based on the discussion, it can be concluded that misconceptions occur in almost every concept Misconceptions were found in the concept of blood plasma (2.1\%), white blood cells (6.2\%), thrombocytes (17.5\%), and blood classification systems (8.2\%). Misconceptions occur because of some student misunderstanding, such as red blood cells that play a role in transporting nutrients, haemoglobin only binds oxygen, white blood cells that fight germs are granular only, and difficulty distinguishing between antigens and antibodies in determining blood groups, blood donation, and impact arising from donations.

\section{Declaration statement}

The authors declare that they have no known competing financial interests or personal relationships that could have influenced the work reported in this paper. 


\section{Reference}

Aisyah, N., \& Widiyanto, B., Fatkhurrohman, M. A. (2019). Efektivitas Penggunaan Alat Peraga Sistem Peredaran Darah terhadap Hasil Belajar Peserta Didik Kelas VII SMP N 12 Kota Tegal. Jurnal Pendidikan MIPA Pancasakti, 2(1), 61-66.

Alfionitari, E., Nurlaeli, N., \& Alfriansyah, D. (2019). Identifikasi Miskonsepsi Siswa Dengan Menggunakan Metode Certainty of Response Index (CRI) Pada Materi Pelajaran IPA. Jurnal Pembelajaran Biologi: Kajian Biologi Dan Pembelajarannya, 6(1), 22-30.

Dewi, F. H., Samsudin, A., \& Nugraha, M. G. (2019). An investigation of students' conceptual understanding levels on fluid dynamics using four-tier test. Journal of Physics: Conference Series 1280, 052037. https://doi.org/10.1088/1742-596/1280/5/052037

Fatmawati, A., Zubaidah, S., Mahanal, S., \& Sutopo. (2019). Critical Thinking, Creative Thinking, and Learning Achievement: How They are Related. Journal of Physics: Conference Series, 1417, 012070. https://doi.org/10.1088/1742-596/1417/1/012070

Fuad, A. Z., Alfin, J., Fauzan, F., Astutik, S., \& Prahani, B. K. (2019). Group Science Learning Model to Improve Collaborative Problem Solving Skills and SelfConfidence of Primary Schools Teacher Candidates. International Journal of Instruction, 12(3), 119-132. https://doi.org/10.29333/iji.2019.1238a

Khairaty, N. I., Taiyeb, A. M., \& Hartati. (2018). Identifikasi Miskonsepsi Siswa Pada Materi Sistem Peredaran Darah Dengan Menggunakan Three-Tier Test di Kelas XI IPA 1 SMA Negeri 1 Bontonompo. Jurnal Nalar Pendidikan, 6(1).

Kurt, H., Ekici, G., Aksu, O., \& Aktas, M. (2013). The most important concept of transport and circulatory systems: Turkish biology student teachers' cognitive structure. Educational Research and Reviews, 8(17), 1574-1593.

Mustofa, Z. (2018). The Description of Student Understanding about Elasticity Concept. Jurnal Penelitian \& Pengembangan Pendidikan Fisika, 4(1), 27-34. https://doi.org/10.21009/1.04104

Mustofa, Z. (2019). Pengaruh Discovery Learning Berbantuan E-Learning Dalam Meningkatkan Penguasaan Konsep Dan Aplikasinya. Kwangsan: Jurnal Teknologi Pendidikan, 7(1), 14-29. https://doi.org/10.31800/jtp.kw.v7n1.p14--29

Mustofa, Z., \& Asmichatin, A. (2019). Modeling Instruction to Promote Student's Understanding of System and Model of System of Mechanical Energy. Abjadia, 3(1), 17. https://doi.org/10.18860/abj.v3i1.5939

Mustofa, Z., Sutopo, \& Mufti, N. (2016). Pemahaman Konsep Siswa SMA Tentang Usaha dan Energi Mekanik (Vol. 1).

Mustofa, Z., Sutopo, S., Mufti, N., \& Asmichatin, A. (2019). The Impact of Modeling Instruction Based on System
Toward Work-Energy Concept Understanding. Jurnal Penelitian \& Pengembangan Pendidikan Fisika, 5(2).

Negoro, R. A., \& Karina, V. (2019). Development Of A FourTier Diagnostic Test For Misconception Of Oscillation And Waves. Jurnal Penelitian \& Pengembangan Pendidikan Fisika, 5(2), 69-76. https://doi.org/10.21009/1.05201

Özgür, S. (2013). The Persistence of Misconceptions about the Human Blood Circulatory System among Students in Different Grade Levels. International Journal of Environmental and Science Education, 8(2), 255-268. https://doi.org/10.12973/ijese.2013.206a

Pujayanto, P. (2018). Developing Four Tier Misconception Diagnostic Test About Kinematics. Jurnal Cakrawala Pendidikan, https://doi.org/10.21831/cp.v37i2.16491 $37(2)$.

Soeharto, B., C., E., S., F.I., D., \& T., S. (2019). A Review of Students' Common Misconceptions in Science and Their Diagnostic Assessment Tools. Jurnal Pendidikan IPA Indonesia, 8(2). https://doi.org/10.15294/jpii.v8i2.18649

Syarafina, Mustofa, Z., \& Prayitno, T. A. (2020). Penerapan Soal Four Tier untuk Mengidentifikasi Miskonsepsi Siswa pada Materi Aktivitas Jantung dan Pembuluh Darah. BIOSFER: Jurnal Biologi Dan Pendidikan Biologi, 5(1), 6-13. https://doi.org/10.23969/biosfer.v5i1.2406

Widiyatmoko, A., \& Shimizu, K. (2018). An overview of conceptual understanding in science education curriculum in Indonesia. Journal of Physics: Conference Series, 983, 012044. https://doi.org/10.1088/1742$6596 / 983 / 1 / 012044$ 


\section{Appendix}

\section{Item related to blood plasma}

Blood is a connective tissue that is looking for something. Blood itself consists of several components that have their respective functions. Blood components that function to transport nutrients are....
A. Blood Plasma
B. Red blood cells (erythrocytes)
C. White blood cells (leukocytes)
D. Blood plates (thrombocytes)
Are you sure?
A. Very Confident
B. Sure
C. Not sure
D. Not sure

Reason:

A. Because nutrients such as food juices and minerals are dissolved in the water in the blood components.

B. Because this blood component has clotting abilities that require large amounts of nutrients.

C. Because this blood component is able to bind oxygen and nutrients at once.

D. Because this blood component is able to maintain nutrition from germs.

Are you sure?
A. Very Confident
B. Sure
C. Not sure
D. Not sure

\section{Items related to red blood cells}

One of the important functions of blood is the transport of airborne oxygen to and from the lungs. Blood components that have this role are....
A. Blood plasma
B. Red blood cells (erythrocytes)
C. White blood cells (leukocytes)
D. Blood plates (thrombocytes)

Are you sure?
A. Very Confident
B. Sure
C. Not sure
D. Not sure

\section{Reason:}

A. Because this blood component has hemoglobin which can only bind oxygen and form oxyhemoglobin ( $\mathrm{HbO} 2$ ).

B. Because this blood component is able to bind carbon dioxide to form and form carbaminohemoglobin ( $\mathrm{HbCO} 2$ ).

C. Because this blood component has hemoglobin which is able to bind oxygen and carbon dioxide in the lungs and body tissues.

D. Because this blood component has amoebaid cells that are able to move places

Are you sure?
A. Very Confident
B. Sure
C. Not sure
D. Not sure

\section{Items related to white blood cells}

There is a component of human blood that acts as an antidote for germs / germs that enter the body. The components of the blood are....

A. Blood plasma

B. Red blood cells (erythrocytes)

C. White blood cells (leukocytes)

D. Blood plates (thrombocytes)

Are you sure?

A. Very Confident

B. Sure

C. Not sure

D. Not sure

\section{Reason:}

A. Because this blood component has granules (coarse grains) as a germ-fighting agent

B. Because this blood component is able to move freely in an irregular and ameboid form to fight germs.

C. Because these blood components amount to millions of antibodies per mm3.

D. Because this blood component has hemoglobin which can fight germs.

Are you sure?

A. Very Confident

B. Sure

C. Not sure

D. Not sure

\section{Items related to thrombocytes}

Surely you have fallen and blisters on your skin. After some time, the wound will freeze and close. What blood components play a role in this process?
A. Blood plasma
B. Red blood cells (erythrocytes)
C. White blood cells (leukocytes)
D. Blood plates (thrombocytes)

Are you sure?
A. Very Confident
B. Sure
C. Not sure
D. Not sure

Reason:

A. Because this blood component has the enzyme thrombokinase which triggers the blood clotting mechanism. 
B. Because this blood component contains nutrients in the form of vitamin $\mathrm{D}$ and iodine which promote wound closure.

C. Because this blood component is red, covering the wound with fibrin threads.

D. Because this blood component has antibodies that kill germs so that the wound closes quickly.

Are you sure?

A. Very Confident

B. Sure

C. Not sure

D. Not sure

\section{Items related to the $\mathrm{ABO}$ blood grouping system}

In the $\mathrm{ABO}$ blood grouping system, the division is based on the difference between antigens and antibodies. If a person with blood type 0 needs a blood donor, the donor must be blood type....
A A
B. B
C. $\mathrm{AB}$
D. 0

Are you sure?

A. Very Confident

B. Sure

C. Not sure

D. Not sure

Reason:

A. Because patients with blood type $O$ have antigens $A$ and $B$, so donors are required to have anti-A and anti-B antibodies as well.

B. Because patients with blood type $O$ have anti-A and anti$B$ antibodies, donors must not have antigen $A$ or antigen $B$

C. Because patients with blood type $O$ have anti-A antibodies, donors should not have A antigens

D. Because patients with blood type $O$ have anti-B antibodies, donors should not have B antigens

Are you sure?

A. Very Confident

B. Sure

C. Not sure

D. Not sure 